\title{
CULTURA E HORIZONTES: ABERTURAS E FECHAMENTOS DO ALFABETO *
}

\author{
Fernando Paulo do Carmo Baptista **
}

\section{DA IMPORTANCIA E DO PAPEL DA LINGUAGEM VERBAL, DAS LÍNGUAS E DA CULTURA}

Na minha perspectiva, aquilo que de modo mais singularizante e distintivo traça a fronteira entre o universo dos entes em si, dos «objectos dinâmicos» de que fala Peirce (Umberto Eco, 1983, 31, 33-34), e o próprio homem é a Cultura, a semiosfera, em cujo centro estruturante opera primordialmente a verbosfera (Lotman e Uspenskij, 1975, 61-95). É ela a marca por excelência da diferenciação ontológica à escala da vida e o critério fundacional da definição axiológica do próprio estatuto social do homem: aquele quid, sem o qual não é possível falar nem de antropogénese nem de antroposfera.

O ser humano, caracterizado por Aristóteles, na Política, como «o único ani-

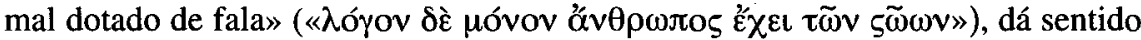
a tudo quanto existe, a tudo quanto pensa, quanto sente ou realiza, através da linguagem verbal. Mais ainda: sem a linguagem verbal, o mundo não era "mundo": era o caos mais negro, mais cego e mudo que imaginar se pode!... É com os potenciais de representação, de configuração, de modelação, de plasmagem, de conformação estruturante, de capacidade instituidora e organizadora que caracterizam os sistemas simbólicos, os sistemas da Cultura - e, entre eles, em primeira instância, o da linguagem verbal e das línguas históricas que a concretizam no tempo e no espaço - que o Homem não só representa o "mundo em si", como o transfigura com as significações que lhe dá, com os saberes com que, explicativamente, o recobre, com as criações culturais que o expandem e transformam. Sem a verbosemiosfera, sem as construções que ela possibilita, sem a informação que ela liberta, organiza e distribui, o saber sobre o Cosmos, sobre a Terra, sobre a Vida e sobre o próprio Homem seria impossível. Toda a energia criadora da Humanidade ficaria irrevelável. No universo inteiro, mesmo povoado de seres de toda a espécie, mesmo recamado dos milhões de galáxias repletas de miríades de estrelas superluminosas, reinaria a escuridão negra do mais absoluto silêncio... Tudo 
“olharia" para tudo sem qualquer sentido que iluminasse essa mirada... Nada nem ninguém, porque seria a mudez de tudo...

Imagine-se um mundo sem o poder interpretante e criador da Cultura: seria um mundo sem a palavra, oral ou escrita, poética ou prosástica, sem os textos da Literatura, do Teatro, da Música, da Pintura, da Escultura, da Arquitectura, da Religião, da Filosofia, da Política, do Direito, da Ciência, da Técnica e da Tecnologia, dos rituais, das celebrações e dos comportamentos sociais; seria um mundo onde a comunicação não existiria, onde a diversidade das ideias não disporia nem de meios ( "media») nem de canais... O sonho da grande "aldeia planetária" daria lugar ao pesadelo de uma absurda comunidade de frios autómatos que se locomoveriam sem alma, sem lógica, sem sentimento e sem sentido.

Creio passar por aqui o significado mais profundo da famosa e bela metáfora com que Martin Heidegger, na Carta sobre o Humanismo, nos dá a linguagem como «a morada do ser» — «das Haus des Seins» - (Heidegger, 1964, 163). Ou seja: o radical acesso do homem a tudo quanto é passa, necessariamente, pelas portas que a linguagem abre ou fecha.

Sabemos como Jürgen Habermas, na sua Teoria do agir comunicacional (1987), defende a tese de que é a linguagem verbal que funda, pragmaticamente, a sociedade humana (Manuel M. Carrilho, 1990, 77), depois de o grande linguista dinamarquês, Louis Hjelmslev, haver afirmado nos seus Prolegomena to a theory of language que a linguagem verbal «é o fundamento último e mais profundo da sociedade humana» (Hjelmslev, 1980, 5).

Outros depoimentos de importantes e consagrados estudiosos e pensadores da actualidade ligados a diversas áreas do saber se poderiam invocar em convergente reforço da ideia da primordial importância da linguagem verbal e das línguas, em tudo quanto diz respeito ao mundo, à vida e ao homem, desde um Karl Otto Apel, do campo da Filosofia da Linguagem, passando por um Karl Popper, do campo da Epistemologia, por um Lévi-Strauss, do campo da Antropologia Cultural, por um Bourdieu, dos campos da Sociologia da Cultura e da Educação, por um Roland Barthes, um Umberto Eco ou um Iurij Lotman, do campo da Semiótica (cf. Baptista, 1989, 130-135; 1993, 175-192; Carrilho, 1990, 44-80 e Brito, 1994, 59-83, 150-181).

Não prescindo, porém, de lembrar, aqui, palavras de um dos vultos maiores do campo da Hermenêutica Filosófica contemporânea, Hans-Georg Gadamer, quando, no seu Wahrheit und Metode (Verdad y Método, na versão espanhola de que me sirvo para citar), afirma: «El que tiene lenguaje "tiene" el mundo» (Gadamer, 1977, 543; para outros desenvolvimentos do tema: 526-585).

É, pois, a partir desse centro de todos os centros que a linguagem é, que se desenvolve toda a nossa experiência e todos os projectos e trajectos de procura, de indagação e de transformação, de nós próprios e do mundo. De facto, o «tener 
lenguaje» de que fala Gadamer não passaria de uma infecunda virtualidadé, se não se traduzisse no domínio efectivo de uma qualquer língua histórica.

Assim o entende o grande linguista Eugenio Coseriu, quando, no seu $\mathrm{El} \mathrm{Hom}$ bre y su lenguaje, afirma que "falar», transformar em acto a faculdade individual e universal da linguagem, «é sempre falar uma língua determinada» (Coseriu, 1977, 16, ss).

Essa língua é para nós, antes de mais, a nossa língua materna, a língua portuguesa.

E é o seu consciente domínio oral e escrito (sobretudo escrito!) que nos possibilita «tener el mundo», ser seus senhores, isto é, interpretá-lo, compreendê-lo, explicá-lo e agir orientadamente sobre ele para o transformar e humanizar.

"Que o mundo é o meu mundo, escreveu L. Wittgenstein $(1987,115,5.62)$, revela-se no facto de os limites da linguagem (da linguagem que apenas eu compreendo) significarem os limites do meu mundo».

No mesmo sentido vai o pensamento do nosso Vergílio Ferreira, quando numa das suas mais belas e profundas reflexões sobre a palavra, inserta em Invocação ao meu corpo (1978, 290 e ss.), afirma, entre outras coisas, que «o mundo é uma proposta muda para que a falada exista», que «o começar a existir é começar a ser dito», que «toda a realidade se cifra à palavra que a enuncia e a faz portanto ser», ou quando, na célebre aula do Para sempre (1984, 193-198), o jovem professor, alto, magro e esgrouviado deste belo romance defende, em sua "lição", que "se não pode pensar senão nos limites da língua», de cujas fronteiras «ninguém pode sair».

Queiramos nós, ou não, sejamos cientistas, filósofos, teólogos, técnicos, juristas, poetas, professores ou alunos, numa palavra, simplesmente cidadãos, sempre que accionamos o nosso sistema linguístico, discorrendo primeiro e enunciando depois, oralmente ou por escrito, criamos "modelos" deste ou daquele ente, deste ou daquele evento, deste ou daquele estado-de-coisas, estático ou dinâmico, de que tomamos conhecimento ou que queremos dar a conhecer para os mais diversos fins. Esses modelos são "textos" e todos eles têm tanto no seu ponto de partida (o da sua criação constitutiva) como no seu ponto de chegada (o da sua recepção e fruição...) a presença tutelar e estruturomorfa da linguagem verbal concretizada numa língua.

Torna-se, deste modo, cada vez mais importante assumir a consciência do papel criativo e construtor, diria mesmo, "poiético" (na acepção semântica que esta palavra matricialmente tem em grego) da linguagem verbal e das línguas, com natural e indiscutível destaque para a língua materna, em todos os actos humanos, em todos os sectores da vida.

"Quem é senhor da linguagem "domina" o mundo", escreveu, como vimos, Hans-Georg Gadamer. Por isso mesmo, cada vez mais se reconhece, hoje, por toda a parte, que a educação linguística e literária é, como afinal sempre foi, pelo 
menos desde a paideia grega, - e digo-o com palavras do Prof. Aguiar e Silva (1987, 21) - «um poderosíssimo instrumento de culturalização e socialização, de desenvolvimento cognitivo, de capacidade crítica, de apuramento da sensibilidade, de potenciação da fantasia lúdica e da criatividade, ao mesmo tempo que constitui o alicerce e o factor sinergético da aprendizagem de outras disciplinas e de outros saberes".

Ora, se é este, em síntese, o poder de uma língua, mais concretamente, daquela língua com que pensamos o mundo e a vida e nos pensamos a nós próprios; com que argumentamos, dialogamos, discutimos ou polemizamos; com que seduzimos ou nos deixamos seduzir e encantar; com que prometemos e juramos, manipulamos ou somos manipulados; daquela língua em que confessamos os nossos afectos, paixões e emoções, manifestamos a nossa vontade, narramos eventos, arquitectamos teorias, formulamos hipóteses e avançamos explicações, construímos mundos e "visões do mundo", meditamos, sonhamos, sofremos, cantamos e rezamos...; se reside em tudo isto, afinal, o fascínio e o sortilégio da sua potestas, afigura-se-me importante aproveitar a oportunidade trazida pela generosa iniciativa destas Jornadas para uma reflexão sobre as consequências que, no que diz respeito ao negativo condicionamento do acesso aos bens da Cultura, decorrem das limitações dessa potestas. Tenho em mente o processo da alfabetização, processo que um recentíssimo e estrangeirado modismo (que se me afigura de duvidosa consistência epistemológica e, porque não dizê-lo, de não menos duvidoso gosto) pretende fazer superar teoreticamente pelo de «literacia», num algo apressado decalque de matriz anglo-americana. Sem questionar, aqui, a validade científico-pedagógica, o interesse sociológico, a oportunidade política ou a bondade antropológica e até mesmo antropofílica do projecto enquanto tal, parece-me que Karl Popper não deixaria de aconselhar aos responsáveis pelo denominado «Estudo Nacional de Literacia» (ligado ao Instituto de Ciências Sociais da Universidade de Lisboa, cf. Noticias da Educação, n. ${ }^{\circ} 18$ de 15 de Fevereiro de 1995, págs. 12-13) o recurso à "navalha de Ockham": «Entia non sunt multiplicanda praeter necessitatem».

Se, numa perspectiva semiótica, a Cultura é definida como a memória não-hereditária de uma comunidade, como a totalidade da informação não-genética e dos meios necessários à sua organização, preservação e transmissão (Lotman e Uspenskij, 1975, 59-95), não deixa de caber, em tal definição, a acção modelizante e estruturante que a mais consistente e actual teorização lhe atribui, quando analisa a orgânica, o funcionamento e o papel de dois dos seus sistemas de significação e de comunicação mais poderosos: o sistema da língua e o sistema da literatura.

O papel fundamental da Cultura consiste, substancialmente, em criar, com base nos repositórios de informação produzida pelo homem, ao longo do tempo, informação nova, cada vez mais poderosa, complexa e rica, e em organizar estruturalmente o mundo que nos rodeia (idem, 64). A Cultura, através do seu núcleo duro 
e operatório que são, por excelência, as línguas naturais, tem esse poder de gerar estruturalidade e operatividade, criando, assim, em derredor do homem, um modo de organização social que é condição da vida em comunidade.

Tal sistema corporiza-se na existência de um complexo conjunto de subsistemas, de "campos" (P. Bourdieu, 1984, 34, 113-120, 136-137; 1989: 27, 64-73 e passim) e de instituições que, multimodamente, engendram, dinamizam e desenvolvem uma vasta rede de estruturas e serviços, de códigos de relações, de valores e de práticas: crenças, tradições, costumes, praxes, comportamentos, modas, estilos, rituais, etc., que configuram as mais importantes, profundas e significativas dimensões históricas do homem - a arte, a mitologia, a religião, a moral, a política, o direito, a educação, a ciência, a técnica, a tecnologia... Em suma: «tudo quanto, nas palavras de Émile Benveniste (1966, 40-41), impregna o homem, onde quer que ele nasça, na sua consciência mais funda, e dirige a sua conduta em todos os modos por que se exprime a sua actividade individual e colectiva», dando forma, conteúdo e sentido à própria Vida e à própria História. E se é por meio de uma língua natural (que possui primigénias propriedades constitutivas, integrativas e estruturomorfas) que o homem assimila a Cultura, a perpetua ou a transforma (Benveniste, ibidem), é inquestionavelmente através da sua modalidade escrita, alfabética, que, de modo mais consistente e palpável, se revela esse seu poder instituinte e estruturante, esse seu papel integrador.

\section{O ALFABETO E A INSTITUIÇÃO ESCOLAR}

Tal é o reconhecimento dessa força do "código escrito" da língua — «We live in what is called a "literate society"» (M. A. K. Halliday, 1985, vii) -, que ler e escrever são praticamente impensáveis, dissociados da instituição escolar e à margem de qualquer reflexão de natureza pedagógica, bem podendo, pois, ver-se no alfabeto a geratriz histórica da Escola, ou seja, dos sistemas educativos. De facto, se observarmos o funcionamento dos nossos estabelecimentos de ensino, desde logo ressalta, do fundo da sua estratégia educativa e da sua dinâmica curricular quotidiana, a presença tutelar do "escrito", a marcar, com incomparável relevância, todo o processo de ensino/aprendizagem, através das suas concretizações, gravadas (in-scritas), quer a título precário, quer a título definitivo, na superfície plana, na face patenteadora, de três inconfundíveis objectos didácticos, tradicionalmente canonizados como símbolos universais da instituição escolar. Refiro-me ao quadro preto, ao caderno e ao livro. Livro que é a condição e a possibilidade das mais diversificadas práticas de leitura e de estudo; quadro e caderno que constituem o indispensável e sempre disponível espaço mediático onde se (pro)movem diferentes práticas de escrita. 
E muito embora no quadro e, sobretudo, no caderno já se possa ver uma espécie de livro embrionário, de livro em potência ou em promessa, onde se ensaiam os primeiros passos da modelação "escritural" do mundo e da vida e onde se cultivam, já mesmo, as primícias aurorais da nossa, como diria Herberto Helder $(1988,44)$, «arte de roseira», é todavia o livro que melhor consubstancia em si o trajecto milenar, percorrido pelo homem desde a invenção da escrita e, muito particularmente, da escrita alfabética, até à constituição, desenvolvimento e pervivente expansão e aperfeiçoamento da poderosa galáxia de Gutenberg (para uma bem fundamentada perspectiva deste trajecto, ver, entre outros, A. Leroi-Gourhan, 1964, 187 e ss.; C. Higounet, 1964; R. Barthes e P. Mauriès, 1987, 146-171 e E. Cazade e C. Thomas, 1987, 173-182).

Não cabe nem nos objectivos nem no âmbito desta reflexão senão uma referência, muito breve e lateral, ao que representou, para a humanidade inteira, a invenção do alfabeto e as subsequentes profundas transformações que tal invenção veio potenciar, ao longo da História. Talvez só uma situação ficcional disso possa dar, figurativamente e pela negativa, uma pálida ideia: estou a ver a pira infernal em que, no "mundo possível" do romance $O$ nome da rosa, de Umberto Eco (1984, 475 e ss.), acabou por se transformar a clausurada e labiríntica biblioteca da abadia. Imagine-se, pois, um tal apocalipse a atingir todas (sublinho: todas) as bibliotecas, todos os escritos, todos os livros e revistas do mundo inteiro!

O quadro-limite, intencionalmente "provocatório", dum apocalipse bibliográfico à escala planetária, assim imaginado pela ficção, poderá ajudar-nos a perspectivar, sob o influxo luminescente e rápido das suas clarificadoras representações imagéticas (estou a pensar particularmente em quem tenha visto o filme), o significado e o alcance da presença do "escrito", do alfabeto, na Terra, ao mesmo tempo que o simbolismo do rescaldo e das cinzas residuais - o deperecimentomorte dos livros, a privação do alfabeto, ou seja, a emergência-epifania do an-alfabetismo - contribuirá, por certo, para sugerir e motivar um reflectido debate (que aqui deixo em aberto) em torno da seguinte cadeia temática e respectivas correlações e implicações: produção editorial $\rightarrow$ bibliotecas $\rightarrow$ sistema educativo $\rightarrow$ escrita/leitura $\rightarrow$ cultura elaborada $\rightarrow$ alfabetização.

É, pois, em clave de alfabeto e com base em algumas das mais fortes sugestões suscitadas pelo fenómeno da alfabetização, de cujas consequências histórico-culturais e funcionais nos dá conta, entre outros, o importante estudo de Jack Goody e de Ian Watt, The consequences of literacy (cf. P. P. Giglioli, 1972, 311-357) consequências essas que vão desde a possibilidade de registo e arquivo memorial do(s) saber(es) até à da sua análise crítica e à da sua criação/produção inovadora - é em clave de alfabeto, dizia, que passo a abordar os seguintes tópicos: a) Alfabetização: um conceito em reanálise; b) Analfabetismo: mais do que de ordem quantitativa, um fenómeno de natureza qualitativa; c) Haverá solução para o 
analfabetismo? A quem interessará a existência de analfabetos? d) Do papel dos intelectuais.

Antes de o fazer, porém, seja-me permitido evocar, aqui, a saudosa memória daqueles que foram os meus professores do ensino primário, em homenagem a todos quantos colocaram em nossas mãos as potencialidades abertas por essa mágica e genesíaca chave, cujo nome, como é sabido, tem origem nas duas primeiras letras do abecedário grego. Lembro, pois, com profunda gratidão, o paciente e dedicado carinho com que aqueles mestres me ensinaram a articular, a correlacionar e a combinar sons e letras, palavras e ideias, em suma, a ler e a escrever, dando, afinal, aquele dinamizador e fecundante impulso que constitui a condição primeira de estar hoje, aqui, a fruir deste inestimável privilégio e rara distinção que lhes quero dedicar, saudosamente.

\section{ALFABETIZAÇÃO: UM CONCEITO EM REANÁLISE}

Em sua estrita acepção literal, a alfabetização é um processo cultural e educativo que, visando fundamentalmente os estratos populacionais mais desfavorecidos e impossibilitados de fruir das vantagens do regime regular e normal de escolaridade, tem como objectivo proporcionar, em suprimento, a aprendizagem da leitura, da escrita e do cálculo, tríade representada simbolicamente pela ideia de alfabeto.

A vigorar, todavia, nesta ponta final do séc. XX, um tão estreito, linear e redutor entendimento da alfabetização, seria como que operar um retorno àquele remotíssimo momento da transição da pré-história para a história da Humanidade.

Assim é que, com vista a uma perspectivação mais profunda e mais ampla do que deverá ser um entendimento correcto da alfabetização, o respectivo Comité Consultivo Internacional da Unesco estabeleceu, para ela, na década de setenta, a seguinte definição (Unesco, Relatório final da $3 .^{a}$ sessão do CCILA, doc. ED/MD 24, de 30.06.72):

«A alfabetização não é a simples leitura de uma palavra, de um conjunto de sílabas e de sons, mas um exercício de compreensão crítica que o homem leva a cabo acerca da sua própria situação em relação à realidade» (sublinhei). E esta perspectiva afigura-se-me consonante com aquela, segundo a qual, já há uns anos antes, René Maheu $(1966,104)$ entendia que, se a alfabetização «é a chave que vai abrir muitas portas, o que importa é o que está para dentro e para além dessas mesmas portas".

Efectivamente, o analfabeto, ao ser, aquando do processo ontogenético da estruturação fundamental dos esquemas e padrões mentais, teoréticos, axiológicos e operatórios, com que pensamos, julgamos, valoramos, agimos e vivemos, o 
analfabeto, dizia, ao ser, então, fortemente limitado na encorporação das basilares componentes constitutivas da sua competência de comunicação verbal (entre elas, o domínio consciente do código oral, mas, sobretudo, do código escrito da língua materna, em sua mais ampla e profunda produtividade funcional e semiótica), fica privado da possibilidade de pleno desenvolvimento dos mais importantes mecanismos e instrumentos da organização e dinamização das aprendizagens, da transacção dos saberes e das experiências, fica impedido de aceder aos mais eficazes métodos de reflexão e de estudo, aos mais ricos e humanizadores programas científicos e culturais. Condenado a operar com uma débil e subalimentada "enciclopédia", com uma nula ou atrofiada e atrofiante "biblioteca", com um indigente e anémico "dicionário", com uma inoperante, porque desorganizada, "gramática" e com uma estreitíssima se não mesmo distorcida "visão do mundo", o analfabeto, exactamente porque é limitado linguisticamente, dificilmente tem consciência de que é limitado em todos os sentidos. Impossibilitado de interpretar, com lucidez crítica, os contextos e situações reais que o envolvem, é alvo preferencial de toda a espécie de manipulações, desde a manipulação política e publicitária, até àquela que é, indubitavelmente, a mais grave de todas as manipulações: a manipulação da consciência!

Num tal estado de coisas, o ético imperativo do Concílio Vaticano II (Documentos, 1976, 390-391), apesar da sua parcimoniosa enunciação, fica ainda bem longe de se fazer cumprir, quando estabelece: «...a todos se deve suficiente abundância (e eu, sem qualquer parcimónia, diria: a todos se deve a maior abundância!) de bens culturais, sobretudo daqueles que constituem a chamada educação básica, a fim de que muitos, por causa do analfabetismo e da privação de uma actividade responsável, se não vejam impedidos de contribuir para o bem comum, de modo verdadeiramente humano». $E$ já não falo na chocante distância a que as situações de flagrante desprezo ou mesmo violação desses fundamentais direitos colocam as pertinentes e justas preocupações e orientações expressas nas várias dezenas de parágrafos que o Catecismo da Igreja Católica (1993, passim) dedica aos problemas da educação e da cultura!

Em tais condições, o analfabeto acaba, em última instância, por ser vítima daquela desumana reificação que transforma as pessoas em "objectos" clausurados na teia da mais cega dependência de tudo e de todos, isto é, em submissos $e$ "pacíficos" sujeitos-residuais, colocados à margem da dinâmica social e do protagonismo do seu próprio tempo histórico.

Por isso é que, na linha da Pedagogia do Oprimido (Paulo Freire, 1972, 29 e ss.), um especialista de craveira internacional, autor de vasta obra pedagógica e co-autor do célebre Apprendre à être (Unesco, 1972), Majid Rahnema, afirma com inequívoca transparência (revista Perspectivas, 1976, 67):

«Para mim, tornar-se um alfabetizado consiste em enveredar pelo caminho que 174 leva da consciência primária (ou seja, aquela que se mostra praticamente imper- 
meável a situações que transcendam a esfera vegetativa da vida) à consciência crítica: é tornar-se um homem de "práxis", com capacidade para entender a realidade e, simultaneamente, a transformar, de maneira a atingir os seus fins; é adquirir uma voz autêntica que possa ligar as palavras à realidade do mundo; é, finalmente, participar na criação de uma cultura de liberdade que substitua a cultura do silêncio".

\section{ANALFABETISMO: MAIS QUE DE ORDEM QUANTITATIVA, UM FENÓMENO DE NATUREZA QUALITATIVA}

O que vem sendo dito não ultrapassa, obviamente, as possibilidades da função consciencializadora da palavra, face à eloquente frieza da quantificação estatística dos analfabetos existentes no mundo, que, como é sabido, constituem seguramente uma das mais cruéis e desumanas realidades do nosso tempo ou, como impressivamente na Unesco se lhe chamou, «o último flagelo do género humano». À escala planetária, o número de analfabetos situa-se na ordem de mil milhões; à escala do nosso país, e segundo dados do INE respeitantes ao censo de 1991 , o seu número, a uma taxa da ordem dos $12 \%$, é superior a um milhão, cifra que nos confere o título nada gratificante de um dos primeiros da Europa, pese embora o significativo progresso que se tem vindo a operar desde o 25 de Abril.

Se se atender, porém, ao facto de que tais dados estatísticos apenas se reportam ao chamado analfabetismo literal ou de primeiro grau, fica de fora, sem ser quantificado, um vasto universo constituído por dois significativos subconjuntos de difícil recenseamento e quantificação, mas de indiscutível influência nos nossos padrões de cultura e de vida.

O primeiro é o do analfabetismo funcional ou regressivo, que congloba um vastíssimo contingente de cidadãos que, tendo beneficiado, muito embora, da primeira alfabetização no âmbito da escolaridade básica, foram sendo, todavia, impedidos pelas adversas condições de vida e de trabalho de pôr em prática toda uma estratégia de continuado aprofundamento e consolidação, ou tão-somente de simples manutenção, acabando por se transformar numa espécie de "heróis trágicos" da necrose educativa e cultural. Um importante estudo, acabado de divulgar pelo Instituto de Ciências Sociais da Universidade de Lisboa, respeitante ao estado da assim chamada «Literacia» em Portugal, aponta para mais de cinco milhões de concidadãos nossos que não sabem interpretar mensagens de natureza prática e de estrutura semântico-sintáctica bastante elementar.

O segundo é o do analfabetismo diplomado, que abarca um largo espectro de indivíduos marcados por uma indisfarçável ignorância que, nada tendo a ver com a docta ignorantia simbolizada pela postura ético-intelectual e pelo exemplo de cidadania de um Sócrates ou de um Nicolau de Cusa, não deixa de ser, porven- 
tura, a expressão mais patética de até onde podém chegar a ousadia e a presunção: «anda em capa de letrado muito asno disfarçado», diz, com sábia propriedade, o expressivo aforismo do nosso povo.

Ao passo que os universos do analfabetismo literal e do analfabetismo regressivo integram, por via de regra, gente simples e bem formada, mas impossibilitada, como ficou referido, de frequentar os normais e fundamentais programas de educação e de ensino que, em princípio, haveriam de potenciar a superação dos rudimentares estádios ontogenéticos em que ficaram a todos níveis, pelo contrário, o universo do analfabetismo diplomado é constituído, dominadoramente, por gente "sem rosto e sem alma", sem escrúpulos, porque marcada pelo agnosticismo, se não mesmo pela iconoclastia, relativamente aos fundamentais padrões axiológicos e éticos que conferem à existência o sentido e a dimensão da dignidade. Incapaz de "jogar o jogo limpo", de se afirmar pelo mérito próprio, pela integridade e pela competência, assume o oportunismo e o expedientismo como método e como "paradigma de vida". É neste vasto, cinzento e nebuloso segmento sócio-antropológico (cumprindo-se, aliás, a lei da recorrência ou iteração relativa dos fenómenos históricos) que atinge o seu auge manifestativo o fenómeno que metaforicamente costumo designar de "jackpotismo (ou grande lotaria) do 25 de Abril" e se situa, a meu ver, um dos pontos germinais da etiologia da subversão de valores e da corrosão das instituições, expressão patológica da preocupante e arrastada crise que tem vindo a atingir, de modo particular, a práxis política do nosso tempo, por forma a gerar um clima de céptico desencanto e de generalizado descrédito, relativamente àquilo que pensamos deveria ser um autêntico projecto social, conformador dos ideais da Democracia.

A uma tal situação não é alheio, como já em outras circunstâncias tenho salientado, aquilo que de tão preocupante se vem passando com o subsistema do Ensino Superior, dado o seu papel estratégico nas dinâmicas fundacionais do Saber, da Educação e da Cultura e na formação fundamental dos nossos mais importantes quadros humanos.

De facto, em vez de constituir o referencial da excelência, do valor e do mérito, em vez de funcionar como espelho da exemplaridade e da virtude e como guardião do que há de mais sagrado e de mais sublime no património, construído e em construção, da nossa História, este nevrálgico sector do nosso Sistema Educativo tem vindo a ser palco, aqui e além, de não raros fenómenos de falta de ética, de probidade e de rigor intelectual, permitindo-se a ocorrência de práticas degradantes na leccionação de cursos desprovidos de qualidade científica e pedagógico-didáctica. Tem-se caído, igualmente, na secundarização da investigação e da actualização, no cúmplice e permissivo apadrinhamento de dissertações como as de mestrado e de doutoramento e na subsequente leviana atribuição dos correspondentes graus e títulos académicos, umas e outros, de muito duvidosa qualidade investigativa e autenticidade autoral e de muito discutível mérito curricular ou, 
pior ainda, na base de meros expedientes de natureza administrativa e promocional, ou no "jogo" pouco transparente da criação e funcionamento, sem critério, de certo tipo de escolas ou institutos, sejam eles públicos, sejam eles privados, que de "superior" pouco mais terão que o nome e a improvisação. Tudo isto, desenhando um quadro sintomatológico configurador daquilo que venho designando de síndrome da terceiro-mundização do Ensino Superior em Portugal, fruto em grande parte da explosão de uma desenfreada "livre concorrência" que tem conduzido, frequentemente, a que os bens da Educação, da Ciência e da Cultura sejam perspectivados e tratados numa bastarda relação de "compra-e-venda" e à luz da mesma lógica mercantil com que se transacciona qualquer "objecto" de consumo corrente. Custa-me a crer que haja alguém que, tendo uma consciência e uma postura intelectual fundadas na Ética do Conhecimento e da Pedagogia e defendendo uma concepção do Ensino Superior consonante com aquela que aqui preconizo, possa aceitar que aqueles inconsumptíveis bens - bens que constituem afinal de contas o perene e inalienável tesouro que faz a excelência da história e da cultura de qualquer país e de qualquer povo! - sejam tratados segundo critérios que defluem duma lógica dominantemente economicista e de mercado! Com esta degradação dos seus primordiais paradigmas axiológicos e culturais, com esta desfiguração dos seus mais nobres e elevados referenciais de aretê, simbolizados na ideia-projecto de Universidade, a "situação clínica" do país, em sua expressão educativa e cultural, não pode deixar de ser considerada como de "prognóstico reservado", havendo quem fale num retorno à "barbárie", no eclipse da cultura pela pseudo-cultura, no crepúsculo da educação pela negação dos valores (cf. Maurice, Henry, 1987).

Que não haja ilusões! Sem o vitalizador influxo das suas mais altas e qualificadas instituições e dos seus melhores cidadãos (oi áristoi: isto é, os mais sábios, os mais competentes, os mais bem formados, os mais capazes, que tão marginalizados têm vindo a ser pelas mediocracias partidárias dominantes), sem o coração pulsante e iluminador dessa verdadeira aristocracia que se funda exclusivamente no valor e no mérito relativo das pessoas, ela poderá muito bem ser o demagógico e vazio argumento da retórica manipuladora dos "políticos", mas a ideia de "democracia" jamais poderá constituir o mobilizador projecto da humanizadora transformação de qualquer povo.

\section{HAVERÁ SOLUÇÃO PARA O ANALFABETISMO? A QUEM INTERES- SARÁ, NO FUNDO, A EXISTÊNCIA DE ANALFABETOS?}

Para a primeira das duas questões aqui enunciadas, têm procurado encontrar resposta, no plano internacional, instâncias tão credenciadas como a UNESCO e a OCDE, através da propositura de bem concebidos e diversificados planos de 
intervenção, que comportam componentes estratégicas de especificação operatória como as seguintes: a) programas de alfabetização elementar, visando o puro analfabetismo literal; b) programas de educação recorrente, destinados a obviar ao fenómeno da regressão, através da consolidação e aprofundamento da alfabetização elementar; c) programas de alfabetização funcional, voltados para o aperfeiçoamento prático de competências já existentes, na perspectiva da fruição do prazer decorrente da realização pessoal do alfabetizando, nos planos profissional, cultural e social; d) programas de formação permanente, tendo como finalidade promover a actualização das competências científicas, pedagógicas, técnico-metodológicas e deontológicas de todos os quadros e agentes, designadamente aqueles que são responsáveis pela acção educativa e pela animação cultural, dentro e fora da instituição escolar.

Tais programas, a que se referem vários números da revista "Perspectivas" (v.g.: os números 0/1972-1975, 2/1977, 2/1978, 2/1979, 1 e 2/1980), quando executados com reflectida competência, dedicado empenhamento e lúcido sentido da realidade, têm produzido resultados encorajadores, muito embora haja a clara noção de que, em alfabetização, é muito difícil operar-se um novo Pentecostes, com o transcendente milagre das línguas de fogo.

Também entre nós se aprovaram leis, se criaram e/ou reformularam estruturas e serviços, se tem vindo a proceder à elaboração de projectos e de programas, à afectação de verbas e à mobilização de outros recursos materiais e humanos, com resultados que, por não terem ainda a desejada expressão quantitativa, nem por isso deverão de algum modo inibir ou frenar o indispensável optimismo de quantos têm a assumida consciência de que as limitações e as dificuldades do país que somos jamais devem fazer perder de vista a complexa causalidade de natureza político-cultural e ético-educativa que, historicamente, está na génese dos nossos analfabetismos.

Assim é que, em meu entender, a resposta à primeira questão - haverá solução para o analfabetismo? - passa pela resposta à segunda: a quem interessará, no fundo, a existência de analfabetos?

Sabemos bem como o processo de alfabetização do Homem se insere no quadro mais vasto da gestão social dos bens simbólicos, também designados de capital cultural, e já vimos, a propósito, como no cerne da importância desses bens, desse capital, se situa o capital linguístico, em virtude da capacidade modelizante e omniformativa, da centralidade estruturomorfa e operatória, da omnipotência semiótica, numa palavra, do insuperável e primordial papel modelador, estruturante, sistematizador e operativo desempenhado pelo binómio "linguagem verbal/línguas naturais", na dinâmica global do sistema da Cultura. Por outro lado, aí temos a História, com a sua insubstituível e sempre esclarecedora e educativa "lição", a ensinar-nos como em todas as épocas as diferentes instâncias do Poder 
se conduziram relativamente ao modo de utilização da língua, sobretudo no que respeita à leitura e interpretação dos textos escritos e às formas de circulação da Cultura. Bem pode evocar-se, aqui, como símbolo paradigmático dessa conduta, o Big Brother do 1984, de George Orwell, com a sua novilíngua! Na verdade, no comportamento de tal personagem-símbolo, está lapidarmente plasmada a monstruosa dimensão de um projecto de controlo e de comando ideológico e axiológico, enquanto estratégia de dominação unanimista e uniformista que, pela superação neutralizadora, segregadora ou liquidatária das "diferenças", visa a manutenção, sem dissidências, sem heterodoxias e sem rivalidades, dos interesses e privilégios decorrentes da detenção e exercício do poder (seja ele social, político, económico, jurídico, religioso ou outro) e das correspectivas esferas de influência, com a conexa teia de nepotismos, clientelismos, carreirismos e oportunismos de toda a ordem.

Todas as épocas da História conheceram, pois, com gradações diversas, o seu Big Brother que, independentemente das variações de "estilo" que as circunstâncias e os contextos lhe impunham ou aconselhavam, manipulou, controlou, disciplinou, domesticou, censurou, discriminou, exorcizou, proscreveu, em cumprimento duma estratégia de dominação que vai desde o clássico panem et circenses da Antiguidade até aos mais sofisticados "telenarcóticos" do nosso tempo, não falando já na inverificação do cumprimento da escolaridade básica ou nos constrangimentos à criação de uma rede nacional de educação pré-escolar.

Sempre o Poder, sempre os poderes, seja qual for o seu suporte institucional (estado, partidos, lobbies, seitas ou igrejas) souberam com clareza bastante "ce que parler veut dire" (para me socorrer do sugestivo título de uma famosa obra dos anos oitenta, da autoria de Pierre Bourdieu), tendo assim consciência do que significa dominar a palavra oral ou escrita, daí defluindo, portanto, a tranquila e assumida segurança de que, uma vez secundarizadas, marginalizadas, se não mesmo silenciadas, as insubmissas e incómodas vozes da verticalidade e da frontalidade, através de maquiavélicos processos de arredamento das principais instâncias de influência, de gestão e de decisão, com analfabetos literais e funcionais (já que os analfabetos diplomados, numa lógica de contrapartidas e na postura subserviente e amenista dos "yes-men", fazem por via de regra o "jogo" de quem pode), ganha outra eficácia a sua estratégia manipuladora, sendo, consequentemente, mais fácil governar (Sobre este tipo de conduta das instâncias do poder, relativamente às práticas da língua, cf. o excelente texto do Prof. Doutor Vítor Manuel de Aguiar e Silva, 1987, 17-24, que segui de perto, bem como a importante e já mencionada obra de P. Bourdieu, 1982).

A quem interessará, pois, a existência de analfabetos?

Face ao que acaba de ser dito, adquirem, porventura, a sua significação mais profunda, tanto a posição expressa por Roland Barthes na sua Leçon $(1977,17)$, quando afirma que na língua, servidão e poder se confundem inelutavelmente, 
como a de Robert-Alain de Beaugrande $(1984,8)$, quando defende que a negação da alfabetização é uma negação da liberdade: «the denial of literacy is a denial of freedom». Nessa perspectiva, cada vez se me afigura mais difícil de refutar a ideia de que a solução para os analfabetismos não é, nem será uma receita acabada e milagrosa. Pelo contrário e em meu entendimento, tal solução é uma solução aberta, complexa e dinâmica, que se corporiza, sim, num apaixonante processo morfogenético, sempre in fieri e sempre in progress, a ser assumido no quadro englobante do axiológico projecto de (in)formação permanente e de transformação humanista e humanizadora de todos os homens. A chave mágica continua a ser ainda o alfabeto, mas, agora, nas valências que defluem da plenitude polissémica que este lexema tem hoje e que vão desde o significado literal e "arqueológico" que lhe advém da matriz etimológica grega, passando pelo significado, mais técnico, de repertório de signos de um qualquer dos sistemas semióticos que configuram, em concreto, o dinamismo global da Cultura, até ao significado epistemológico-estratégico (com este último correlacionado) de sistema de saberes fundamentais com que se organiza e opera o discurso de qualquer ciência ou arte (ex: o "alfabeto" da Física, da Biologia, da Informática, da Música, da Pintura ou do Cinema). Dessa forma e com tais aberturas, a ideia de «alfabetização» passará a ser o permanente e qualitativo referencial para os mais avançados e inovadores projectos de investigação, de formação e de aprofundamento cultural, ético-axiológico e educativo de todo e qualquer ser humano, letrado ou não letrado, e independentemente da posição que ocupa ou do estatuto de que goza na sociedade, e o «alfabeto» deixará de ser, cada vez mais, o incontornável factor de exclusão e marginalidade, a tão poderosa quanto perversa chave de discriminação preconceituosa e clausurante $\mathrm{e}$, consequentemente, a principal geratriz, que tem sido, das mais graves situações de desigualdade social. Que no «Sermão da Montanha» para o milénio que se avizinha, uma nova bem-aventurança se possa inscrever definitivamente: Bendito $o$ orbe da Terra, pois que todos os seus filhos sabem finalmente ler!

\section{DO PAPEL DOS INTELECTUAIS}

Seja-me permitida, para terminar, ainda uma breve palavra acerca do papel dos intelectuais na superação deste e de outros estados-de-coisas que, no fundo, se integram na realização histórica do axiológico e transformador projecto a que acabei de me referir.

É minha convicção sincera de que a todos quantos, na recolhida clausura do silêncio que medita, se dedicam, quotidianamente e pela noite dentro, a estudar as realidades do mundo e a criar as mensagens que, a partir delas e acerca delas, multimodamente se vão plasmando no imparável caudal dos textos da Cultura, é minha conviç̧ão, repito, de que a todos eles cabe não tanto o papel de actores do Poder, de decisores das coisas da política, mas antes, o primordial "estatuto" de 
informados e lúcidos activadores da memória do passado, de serenos e isentos analistas-intérpretes do presente e dos "ventos da História" que nele vão soprando, de inspirados áugures dos horizontes venturos. Cabe-lhes, por outras palavras, procurar, no passado, as raízes da nossa mais funda identidade cultural $\mathrm{e}$, assim, as mais consistentes bases de fundamentação de qualquer projecto a realizar; captar criticamente os indícios e sintomas dos fenómenos cruciais que se revelam no presente e proceder à formulação (correctamente enquadrada sob os pontos de vista gnosiológico, axiológico e metodológico) das grandes hipóteses resolutivas dos problemas vitais que se colocam ao mundo, à vida e ao homem; cabe-lhes, em suma, rasgar novos horizontes, traçando os rumos e as rotas humanamente mais credíveis para o ingresso no futuro.

Nesse contexto, assume especial relevância o seu empenhamento na promoção do diálogo polifónico entre as contribuições provenientes dos vários quadrantes de pensamento, com o subjacente respeito pela diversidade das mundividências e das valorações e a permanente defesa da plena afirmação das diferenças (cf. J. Simon, 1990, 220-221; G. Vattimo, 1988,161-187 e A. Jacquard, 1978, 185-188). É neste constante e persistente esforço de alargamento da capacidade dialógica (polilógica), interdiscursiva e intercultural, que adquire sentido autêntico o seu "estatuto" de mais autorizados e qualificados fruidores das potencialidades trazidas à História pela invenção do alfabeto, condição essa que eticamente os obriga a uma constante "lição" de humildade intelectual, de liberdade responsável, de fecundo relativismo e de compreensiva e generosa tolerância. Em suma: porque fruidor privilegiado dos poderosos mecanismos que organizam o mais nobre dos capitais humanos - o capital da Cultura -, um intelectual só é digno desse nome, quando sabe ser, por excelência, isto é, com ética verticalidade, com escrupulosa isenção, com transparente frontalidade e com sempre actualizada e sólida competência, um paradigma de homo dialogans, de homo cultus, sempre disponível para tentar responder, serenamente, às inquietantes e nodais questões que o seu tempo lhe coloca, às profundas, misteriosas e porventura irrespondíveis perguntas que, no poético diálogo, lhe vai lançando o sempre inspirado e rebelde Orfeu (Miguel Torga, poema «Diálogo», in Antologia Poética, 213):

Pergunto...

Mas quem me poderia responder?!

Tu, não, rio sem asas,

Que permaneces

A passar...

Nem tu, planeta alado,

Que pareces

Parado

A caminhar... 


\author{
Humano, só de humanos meus iguais \\ Entendo a fala, \\ Os gestos \\ E o destino. \\ E esses, como eu, \\ Olham a terra e o céu, \\ Os rios e os planetas, \\ E perguntam também...
}

\title{
Perguntam, mas a quem?
}

Quando se assiste ao promissor fenómeno que costumo designar de parabolicização (ou, numa outra perspectiva, de internetização) das comunidades, das línguas e das culturas (à partida tão diferenciadas e tão distantes), com a consequente aproximação dos povos, a relativização do conhecimento e dos padrões axiológicos e a derrocada de velhos muros, parece que novos horizontes se rasgam definitivamente para a Humanidade. Persiste, todavia, um sentimento de desencanto, de perplexidade e de angústia, decorrente da sensação de "ausência" de referenciais a todos os níveis, com especial destaque para o sistema de valores, sobretudo em consequência da crise da Metafísica, denunciada pelo famoso e trágico grito nietzcheiano do «Gott ist tot!» (cf. Heidegger, 1968, 173-219), grito que, em seu simbolismo profundo, ecoa pelo nosso tempo, como um rebate de orfandade e de luto, como uma deriva sem sentido ou com o sentido do absurdo e da morte.

Esta atmosfera de desiludente negrume, se não mesmo de deceptivo e desolador desconcerto, não deve, porém, dar lugar ao pessimismo. Tanto a "lição" da História como as potencialidades da Cultura justificam, sem euforias, é certo, uma perspectiva optimista que não dispensa, todavia, a reflexão desapaixonada, o estudo rigoroso, o trabalho persistente, o empenhamento solidário. É na generosa dádiva de realizações como a destas Jornadas que se transcende a finitude da nossa condição humana e se vão antecipando as desejadas aberturas de horizonte, seja ele relativo, seja ele absoluto.

Um belo poema de Ramos Rosa, intitulado «Nós somos», plasma, entre desencanto e esperança, certos aspectos marcantes da mundividência de homens como os da minha geração:

«Como uma pequena lâmpada subsiste e marcha no vento, nestes dias, na vereda das noites, sob as pálpebras do tempo. 
Caminhamos, um país sussurra, dificilmente nas calçadas, nos quartos, um país puro existe, homens escuros, uma sede que arfa, uma cor que desponta no muro, uma terra existe nesta terra.

Como uma pequena gota às vezes no vazio, como alguém só no mar, caminhando esquecidos, na miséria dos dias, nos degraus desconjuntados, subsiste uma palavra, uma sílaba de vento, uma pálida lâmpada ao fundo de um corredor, uma frescura de nada, nos cabelos, nos olhos, uma voz num portal e a manhã é de sol.

Uma pequena ponte, uma lâmpada, um punho, uma carta que segue, um bom dia que chega, hoje, amanhã, ainda, a vida continua, no silêncio, nas ruas, nos quartos, dia a dia, nas mãos que se dão, nos punhos torturados, nas frontes que persistem.»

É uma axioma de existência (prerrogativa do código biopsicosférico humano) afirmar que os jovens sempre foram e continuarão a ser a garantia da perpetuação genética e cultural do nosso país. Porque acredito no futuro, tenho também de compreender as irreverências contestatárias e, sobretudo, acreditar na inventiva sonhadora dos jovens da actual geração. Geração em crise, é certo, que sofre as consequências de outras prolongadas situações de crise que têm raízes profundas pelo menos em gerações como a minha. Com alguma justeza, mas também com igual ou maior injustiça, vem sendo a actual geração de jovens apodada de «rasca», quando a muitos dos adultos, pais e até altos dirigentes, esses sim, com grandes responsabilidades no actual estado-de-coisas, caberá porventura com maior pertinência um tal epíteto. Por razões de homologia funcional inerente aos cargos que tenho desempenhado no campo da educação e da instituição escolar, confio nos jovens. Acredito que os seus nobres ideais, as suas energias criadoras se vão mobilizar, mais cedo do que tarde, ao apelo consciencializador, sereno e firme daqueles outros adultos que ainda vai havendo (também eles pais, educadores e dirigentes, mais responsáveis, mais competentes e mais sérios) contra o egoísmo hedonista e materialista, contra o consumismo acrítico e gratuito, contra a droga e toda a espécie de poluição e agressão moral e ecológica, contra a fruição sem ética, sem estética, sem autodomínio e sem bússola, contra a contestação sem critério e sem regras, contra a subalternização do mérito e do valor, contra a 
permissividade, o oportunismo e a corrupção, contra a desfiguração da alma e do rosto do homem pelo esvaziamento da sua própria humanidade. Acredito, sinceramente acredito que da mobilização dessas imensas potencialidades e capacidades, tudo caldeado com a experiência, a prudência, a "visão" e a sageza daqueles raros mas avisados e "aristocráticos" senatores, haja de surgir a certeza da modelação do país que vemos figurado no esperançoso poema de Ruy Belo, «O portugal futuro»:

«O portugal futuro é um país

aonde o puro pássaro é possível

e sobre o leito negro do asfalto da estrada

as profundas crianças desenharão a giz

esse peixe da infância que vem na enxurrada

e me parece que se chama sável

Mas desenhem elas o que desenharem

é essa a forma do meu país

e chamem elas o que lhe chamarem

portugal será e lá serei feliz

Poderá ser pequeno como este

ter a oeste o mar e a espanha a leste

tudo nele será novo desde os ramos à raiz

À sombra dos plátanos as crianças dançarão

e na avenida que houver à beira-mar

pode o tempo mudar será verão

Gostaria de ouvir as horas do relógio da matriz

mas isso era o passado e podia ser duro

edificar sobre ele o portugal futuro.»

\section{NOTAS}

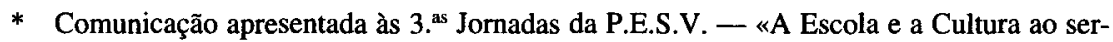
viço da Vida», dedicada a D. António Monteiro, Bispo de Viseu (evocando uma sua recente reflexão pastoral sobre o(s) analfabetismo(s)).

\section{REFERÊNCIAS BIBLIOGRÁFICAS}

AGUIAR E SILVA, Vítor Manuel, 1987, «Língua materna e sucesso educativo», in revista Diacrítica, n. ${ }^{\text {os }} 3-4 / 1988-89$, Braga, Centro de Estudos Portugueses da Universidade do Minho. 
crítica, n. ${ }^{\text {os }} 3-4 / 1988-89$, Braga, Centro de Estudos Portugueses da Universidade do Minho; 1993, «Língua materna e modelação do mundo», ibidem, n. ${ }^{\circ} 8 / 93$.

BARTHES, Roland, 1977, La leçon, Paris, Seuil.

BARTHES, R. e MAURIÈS J P.; CAZADE, E. e THOMAS, C., 1987, Respectivamente, artigos Escrita e Alfabeto, vol. 11 da Encicl. Einaudi, trad. port. da Imprensa Nacional - Casa da Moeda.

BEAUGRANDE, R.- A. de, 1984, Text production. Toward a science of composition, Norwood, Ablex.

BENVENISTE, Emile, 1966, Problèmes de linguistique générale, Paris, Gallimard.

BOURDIEU, Pierre, 1982, Ce que parler veut dire (l'économie des échanges linguistiques), Paris, Fayard; 1984, Questions de Sociologie, Paris, Minuit; 1989, O Poder Simbólico, Lisboa, Difel.

BRITO, António José, 1994, «A linguagem, ponto de partida da Filosofia?», in Razão e Dialéctica. Estudos de Filosofia e História da Filosofia, Lisboa, Imprensa Nacional - Casa da Moeda.

CARRILHO, Manuel Maria, 1990, Verdade, Suspeita e Argumentação, Lisboa, Presença.

CATECISMO DA IGREJA CATÓLICA, 1993, Coimbra, Gráfica de Coimbra.

COSERIU, Eugenio, 1977, El hombre y su lenguaje, Madrid, Gredos.

ECO, Umberto, 1980, Il nome della rosa, cit. pela trad. port. da Difel; 1983, Lector in fabula, Lisboa, Editorial Presença (trad. port. com o título de Leitura do Texto Literário).

FERREIRA, Vergílio, ${ }^{2} 1978$, Invocação ao meu corpo, Lisboa, Livraria Bertrand; 1984, Para sempre, Lisboa, Livraria Bertrand.

FREIRE, Paulo, 1972, Pedagoqia do Oprimido, Porto, Afrontamento.

GADAMER, Hans-George, 1977, Verdad y Método, Fundamentos de una hermenéutica filosófica, Salamanca, Ediciones Sígueme.

GIGLIOLI, Pier Paolo, 1972, Language and social context, Harmondsworth, Penguin Books. HABERMAS, Jürgen, 1987, Théorie de l'agir communicationnel, Paris, Fayard.

HALLIDAY, M. A. K., 1985, An Introduction to Functional Grammar, London, E. Arnold. HEIDEGGER, Martin, 1964, Lettre sur l'Humanisme, Paris, Aubier Montaigne.

HEIDEGGER, Martin, 1968, Chemins qui ne mènent nulle part, Paris, Gallimard.

HELDER, Herberto, 1988, Última Ciência, Lisboa, assírio \& alvim.

HENRY, Maurice, 1987, La Barbarie, Paris, Grasset.

HIGOUNET, C., 1964, L'écriture, Paris, PUF, col. "Que sais-je?".

HJELMSLEV, Louis, 1961, Prolegomena to a Theory of Language, cit. pela trad. ital. de G. C. Lepschy, Torino, Einaudi, 1980.

JACQUARD, Albert, 1978, Eloge de la différence - La génétique et les hommes, Paris, Seuil, cit. pela trad. port. de Public. Europa-América.

NOTÍCIAS DA EDUCAÇÃO, 1995, n. ${ }^{\circ} 18$, de 15 de Fevereiro.

LEROI-GOURHAN, A., 1964, Le geste et la parole - technique et langage, Paris, Edit. A. Michel, cit. pela trad. port. de Edições 70.

LOTMAN, J. M. e USPENSKIJ, B. A., 1975, Semiotica e Cultura, Milano-Napoli, Riccardo Ricciardi Editore.

RAHNEMA, M., 1976, Revista Perspectivas (UNESCO), vol. VI, n. ${ }^{\circ} 1 / 1976$, Lisboa, Livros Horizonte.

SIMON, Josef, 1990, Filosofia da Linguagem, Lisboa, Edições 70.

TORGA, Miguel, 1981, Antologia Poética, Coimbra, Gráfica de Coimbra.

VATICANO II, 1976, Documentos, Braga, S.N.A.O.

VATTIMO, G., 1988, As Aventuras da Diferença, Lisboa, Edições 70.

WITTGENSTEIN, Ludwig, 1987, Tratado Lógico-Filosófico. Investigações Filosóficas, Lisboa, Fundação Calouste Gulbenkian. 